\title{
Chemical Composition of Laurencia obtusa Extract and Isolation of a New $\mathrm{C}_{15}$-Acetogenin
}

\author{
Hélène Esselin ${ }^{1}$, Sylvain Sutour ${ }^{1}$, Joana Liberal ${ }^{2,3}$, Maria Teresa Cruz ${ }^{2}$, Ligia Salgueiro ${ }^{2}$, \\ Benjamin Siegler ${ }^{4}$, Ingrid Freuze ${ }^{4}$, Vincent Castola ${ }^{1}$, Mathieu Paoli ${ }^{1}$, Ange Bighelli ${ }^{1}$ and \\ Félix Tomi ${ }^{1, *}$
}

1 Université de Corse-CNRS, UMR 6134 SPE, Equipe Chimie et Biomasse, Route des Sanguinaires, 20000 Ajaccio, France; helene.esselin@gmail.com (H.E.); ssutour@aol.com (S.S.);

vincent.castola@univ-corse.fr (V.C.); mathieu.paoli@univ-corse.fr (M.P.); ange.bighelli@univ-corse.fr (A.B.)

2 CNC.IBILI/Faculty of Pharmacy, University of Coimbra, Health Sciences Campus, Azinhaga de S. Comba, 3000-548 Coimbra, Portugal; joanaliberal@gmail.com (J.L.); trosete@ff.uc.pt (M.T.C.); ligia@ff.uc.pt (L.S.)

3 Escola Superior de Saúde Dr. Lopes Dias, Instituto Politécnico de Castelo Branco, Campus da Talagueira, 6000-767 Castelo Branco, Portugal

4 Plateforme d'Ingénierie et d'Analyses Moléculaires, Université d'Angers, UFR Sciences, 49000 Angers, France; benjamin.siegler@univ-angers.fr (B.S.); ingrid.freuze@univ-angers.fr (I.F.)

* Correspondence: felix.tomi@univ-corse.fr; Tel.: +33-495-52-4122

Academic Editor: Derek J. McPhee

Received: 11 April 2017; Accepted: 6 May 2017; Published: 11 May 2017

\begin{abstract}
A new $\mathrm{C}_{15}$-acetogenin, sagonenyne (20), exhibiting an unusual single tetrahydropyran ring was isolated from an ethyl acetate extract of Laurencia obtusa collected on the Corsican coastline. Its structure was established by detailed NMR spectroscopic analysis, mass spectrometry, and comparison with literature data. Twenty-three known compounds were identified in the same extract by means of column chromatography steps, using a ${ }^{13} \mathrm{C}-\mathrm{NMR}$ computer aided method developed in our laboratory. In addition to sesquiterpenes, which represent the main chemical class of this extract, diterpenes, sterols, and $C_{15}$-acetogenins were identified. The crude extract was submitted to a cytotoxicity assay and was particularly active against THP-1 cells, a human leukemia monocytic cell line.
\end{abstract}

Keywords: Laurencia obtusa; ${ }^{13}$ C-NMR; corsica; cytotoxic activity; sagonenyne

\section{Introduction}

Marine organisms are shown to be a large source of natural products with unusual structures and exhibiting a wide range of bioactivities. The genus Laurencia (Ceramiales, Rhodomelaceae) is one of the most studied among red algae. Species of this genus are mainly characterized by the presence of sesquiterpenes, di- and triterpenes, sterols, alkaloids and $\mathrm{C}_{15}$-acetogenins [1]. These secondary metabolites are usually distinguished by the presence of at least one halogen atom [2]. Laurencia obtusa (Hudson) J. V. Lamouroux is the type species of this genus.

A large number of metabolites isolated from Laurencia species have been evaluated for their in vitro cytotoxic activity against several human tumor cells [3-5]. For now, the cytotoxic activity cannot be corroborated with the presence or absence of a functional group in the molecules.

In the course of our study on the constituents of Mediterranean seaweeds [6,7], we investigated the chemical composition of a Laurencia species growing wild in Corsica. We describe in this context the secondary metabolites present in Laurencia obtusa ethyl acetate extract and its cytotoxic activity, as well as the structure elucidation of a new $\mathrm{C}_{15}$-acetogenin derivative. 


\section{Results}

All samples (crude extract and chromatography fractions) were submitted to the ${ }^{13}$ C-NMR computer aided method developed in our laboratory [8]. This method allows identification of individual components with limited fractionations, by comparison of the signals of the mixture spectrum with those of reference spectra present in a laboratory-built library. A library dedicated to marine components has been created, using spectral data associated with usual marine organisms' components from the literature. This library contains more than 2000 entries belonging to numerous families-mono-, sesqui-, and diterpenes; sterols; $\mathrm{C}_{15}$-acetogenins; and fatty acids-which exhibited a wide range of skeletons.

Each compound is identified by taking into account three parameters directly available from the software: the number of carbon observed compared to what is expected, the difference between the chemical shift of each signal in the mixture and those from reference spectral data $(\Delta \delta)$, and the number of overlapped signals of carbons belonging to two components that fortuitously possess the same chemical shift.

This method, applied to essential oils [9] and to various plant extract analysis [10] has demonstrated reliable results, using both libraries constructed with spectra recorded in our laboratory under the same experimental conditions (solvent, concentration, data treatment), and libraries built with literature data [11,12]. The analysis of Laurencia obtusa extract was realized by a combination of chromatographic $\left(\mathrm{CC} \mathrm{SiO}_{2}\right.$, Sephadex $\left.{ }^{\circledR} \mathrm{LH}-20\right)$ and spectroscopic $\left({ }^{13} \mathrm{C}-\mathrm{NMR}\right)$ techniques.

\subsection{Chemical Composition of Laurencia obtusa Extract}

\subsubsection{Validation of ${ }^{13} \mathrm{C}-\mathrm{NMR}$ Method on Crude Extract}

The direct analysis of Laurencia obtusa crude extract allowed the identification of 5 sesquiterpenes: $\beta$-(1) and $\alpha$-snyderol (2) (Table 1), epibrasilenol (3), brasilenol (4), and 4-hydroxy-5-brasilene (5) (Table 2; Figure S3). $\alpha$-Snyderol and 4-hydroxy-5-brasilene have firstly been isolated from L. obtusa [13,14] and $\beta$-snyderol from L. snyderae [13]. Brasilenol and epibrasilenol were identified in Aplysia brasiliana [15], a marine mollusk which feeds on various algae including Laurencia species.

Table 1. Chemical shifts of $\beta$-snyderol in $\mathrm{CDCl}_{3}$.

\begin{tabular}{ccc}
\hline $\mathbf{C}$ & $\delta$ Extract (ppm) & $\delta$ Litt [13] (ppm) \\
\hline $\mathbf{1}$ & 111.80 & 111.8 \\
$\mathbf{2}$ & 145.07 & 144.9 \\
$\mathbf{3}$ & 73.40 & 73.3 \\
$\mathbf{4}$ & 41.27 & 41.3 \\
$\mathbf{5}$ & 20.61 & 20.6 \\
$\mathbf{6}$ & 53.15 & 53.1 \\
$\mathbf{7}$ & 145.57 & 145.6 \\
$\mathbf{8}$ & 37.47 & 37.4 \\
$\mathbf{9}$ & 35.94 & 35.9 \\
$\mathbf{1 0}$ & 67.44 & 67.1 \\
$\mathbf{1 1}$ & 42.10 & 41.9 \\
$\mathbf{1 2}$ & 28.44 & 28.4 \\
$\mathbf{1 3}$ & 16.37 & 16.4 \\
$\mathbf{1 4}$ & 109.16 & 109.0 \\
$\mathbf{1 5}$ & 27.78 & 28.1 \\
\hline
\end{tabular}


Table 2. Compounds identified in Laurencia obtusa extract.

\begin{tabular}{|c|c|c|c|c|}
\hline $\mathbf{N}^{\circ}$ & Components & $\mathrm{NMR}^{3}$ & Overlap $^{4}$ & References \\
\hline \multicolumn{5}{|c|}{ Sesquiterpenes } \\
\hline 1 & $\beta$-snyderol ${ }^{1}$ & $15 / 15$ & 4 & [13] \\
\hline 2 & $\alpha$-snyderol ${ }^{1}$ & $12 / 15$ & 3 & [13] \\
\hline 3 & Epibrasilenol $^{1}$ & $15 / 15$ & 1 & [15] \\
\hline 4 & Brasilenol $^{1}$ & $13 / 15$ & 1 & [15] \\
\hline 5 & 4-hydroxy-5-brasilene ${ }^{1}$ & $15 / 15$ & 1 & [14] \\
\hline 6 & laurene & $15 / 15$ & 0 & [16] \\
\hline 7 & $\alpha$-bromocuparene & $15 / 15$ & 1 & [17] \\
\hline 8 & $\alpha$-isobromocuparene & $15 / 15$ & 3 & [17] \\
\hline 9 & laurinterol & $15 / 15$ & 3 & [18] \\
\hline 10 & iso-laurenisol & $15 / 15$ & 0 & [19] \\
\hline 11 & 3,7-dihydroxydihydrolaurene & $15 / 15$ & 1 & [4] \\
\hline 12 & laurane derivative & $15 / 15$ & 0 & (compound $\mathbf{1}$ in [3]) \\
\hline 13 & laurane derivative & $15 / 15$ & 0 & (compound 10 in [20]) \\
\hline 14 & 11-iodolaurinterol & $15 / 15$ & 0 & [21] \\
\hline \multicolumn{5}{|c|}{$\mathrm{C}_{15}$-acetogenins } \\
\hline 15 & 3-(E)-laurenyne & $14 / 15$ & 0 & {$[22]$} \\
\hline 16 & (Z) linear acetogenin & $15 / 15$ & 2 & (compound 3 in [23]) \\
\hline 17 & (E) linear acetogenin & $15 / 15$ & 1 & (compound 4 in [23]) \\
\hline 18 & 13-(E)-epipinnatifidenyne & $15 / 15$ & 4 & [24] \\
\hline 19 & (E)-dihydrorhodophytin & $15 / 15$ & 5 & [25] \\
\hline 20 & Sagonenyne ${ }^{2}$ & $15 / 15$ & 0 & - \\
\hline \multicolumn{5}{|c|}{ Diterpenes } \\
\hline 21 & neorogioldiol & $20 / 20$ & 3 & [26] \\
\hline 22 & obtusadiol & $20 / 20$ & 2 & [27] \\
\hline \multicolumn{5}{|c|}{ Sterols } \\
\hline 23 & fucosterol & $29 / 29$ & 12 & {$[28]$} \\
\hline 24 & cholesterol & $27 / 27$ & 12 & [29] \\
\hline
\end{tabular}

1: Compounds identified directly from L. obtusa crude extract; ${ }^{2}$ : New compound isolated from chromatography fractions; ${ }^{3}$ : Number of observed signals compared to number of expected signals; measured in NMR spectra of the crude extract (1-5) or fractions (6-24); ${ }^{4}$ : Number of overlapped signals; measured in NMR spectra of the crude extract (1-5) or fractions (6-24).

The ${ }^{13} \mathrm{C}-\mathrm{NMR}$ spectrum exhibited a series of 15 chemical shifts with high intensities corresponding to those of $\beta$-snyderol which is obviously the main component of this extract. Table 1 shows comparison between $\beta$-snyderol ${ }^{13} \mathrm{C}$-NMR data obtained from our extract and those from literature. For this compound, the $\Delta \delta$ ranged from 0.00 to $0.34 \mathrm{ppm}$, most of them are however inferior to $0.15 \mathrm{ppm}$. The number of overlapped signals for this molecule (4) is due to the presence of an isomer ( $\alpha$-snyderol) which differs only by the position of a double bond and exhibits close chemical shifts to those of $\beta$-snyderol. However, it does not avoid a proper identification since each component possesses characteristic chemical shifts which differ from one isomer to another.

Concerning these five molecules ( 1 to 5 ), the number of overlapped signals (up to four), the chemical shift disparities between our extract and the literature (mostly inferior to $0.15 \mathrm{ppm}$ ) and the number of observed signals (only quaternary carbons were not observed for some components) fulfill the conditions for a proper identification (Table 2).

\subsubsection{Application of ${ }^{13} \mathrm{C}-\mathrm{NMR}$ Method to Chromatography Fractions}

In order to get a better overview of the L. obtusa chemical composition, the crude extract was submitted to column chromatography (CC) and 17 fractions were obtained and analyzed by ${ }^{13} \mathrm{C}-\mathrm{NMR}$. This fractionation allows the identification of 18 supplementary components (compounds 6 to 19 and 21 to 24 ) including seven laurane derivatives $(6,9-14)$, two cuparane derivatives (7 and 8), two linear C15-acetogenins (16 and 17), three cyclic $C_{15}$-acetogenins $(\mathbf{1 5}, \mathbf{1 8}, \mathbf{1 9})$, two diterpenes (21 and 22), and two sterols (23 and 24) (Table 2). They all possess skeleton commonly found in Laurencia species.

All these molecules (6-24) were identified by comparison of their chemical shifts in the fractions with literature data. Each carbon was observed except the quaternary one of 3-(E)-laurenyne. Most of 
$\Delta \delta$ values were inferior to $0.15 \mathrm{ppm}$. For most components, the number of overlapped signals was low ( 0 to 5 ) but the sterols ( 23 and 24 ) exhibited up to 12 overlapped signals over 27 and 29 . Indeed, only the side chain differed from one derivative to another, leading to some overlapped signals. However, each molecule possessed enough characteristic signals to be clearly distinguished from one to another. Moreover, relative resonance intensities help the attribution of the series of chemical shifts.

\subsection{Structure Elucidation of Compound 20}

After identification of the known compounds with the library generated in our laboratory, the same set of 15 chemical shifts remained unassigned in the ${ }^{13} \mathrm{C}-\mathrm{NMR}$ spectrum of fractions F6 to F9. Combined repetitive chromatographies (CC on silica gel using a gradient of solvents and size-exclusion on sephadex LH-20) were implemented in order to isolate this compound (20).

Combination of information provided by DEPT spectrum $\left(3 \mathrm{C}, 9 \mathrm{CH}, 4 \mathrm{CH}_{2}\right.$ and $\left.2 \mathrm{CH}_{3}\right)$ and by ${ }^{1} \mathrm{H}$ and ${ }^{13} \mathrm{C}$ chemical shift values suggested the presence of a 2-penten-4-ynyl moiety: $\left[\delta_{\mathrm{H}} 2.85(1 \mathrm{H}, \mathrm{d}\right.$, $J=2.0 \mathrm{~Hz}), 5.55(1 \mathrm{H}, \mathrm{dd}, J=15.9$ and $2.0 \mathrm{~Hz})$, and $6.22(1 \mathrm{H}, \mathrm{dt}, J=15.9$ and $7.1 \mathrm{~Hz}) ; \delta_{\mathrm{C}} 81.55,77.21$, 112.13 and 141.29]. Moreover, the $J$-value $(15.9 \mathrm{~Hz})$ measured between $\mathrm{H}-3$ and $\mathrm{H}-4$ ensured the $E$ stereochemistry of the double bond. 1D NMR spectra also revealed the presence of an acetoxyl group [ $\delta_{\mathrm{H}} 2.13(3 \mathrm{H}, \mathrm{s}), \delta_{\mathrm{C}} 170.19$ and 20.87].

Based on the ${ }^{13}$ C-NMR spectra (Table 3), substituent at C-7, C-9, C-10, and C-13 are oxygen atoms $\left(\delta_{C} 71.38,76.25,69.95\right.$ and 83.98 respectively) whereas those at C-6 and C-12 are halogen atoms (55.52 and 47.50). Chemical shift value at H-7 $\left(\delta_{\mathrm{H}}\right.$ 5.23) revealed that the acetoxyl group is linked to this carbon.

Most of the time, algal $\mathrm{C}_{15}$-acetogenins are cyclic ether metabolites with different ring sizes. Consequently, HMBC experiment will be needed to observe a connectivity between oxygenated methines, and to determine the size of the ether cycle. HMBC allowed the writing of the planar formula represented on Figure 1. Indeed, a long-range correlation between H-9 and C-13 has been observed. The presence of a connection between C9 and C13, through an oxygen atom, confirmed a tetrahydropyran ring system (Figure S1).

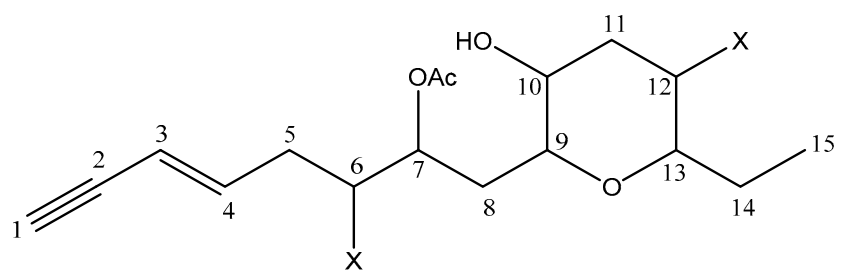

Figure 1. Planar structure for sagonenyne (20); $X=$ halogen atom.

The group of acetogenins containing a six-membered cyclic ether ring includes only 14 compounds isolated from Laurencia species or mollusks grazing on these algae. Among them, four components exhibited one single tetrahydropyran ring, and only two were isolated directly from a Laurencia species: bisezakyne-B and scanlonenyne [2]. Bisezakyne-B has been isolated from a Japanese Laurencia species [30] whereas scanlonenyne has been detected in a L. obtusa specimen from Irish waters [31]. Bisezakyne-B and compound (20) exhibit similar structures since their carbon C-7 carry an acetoxyl group, instead of a carbonyl group for scanlonenyne (Figure 2). Even though ${ }^{13} \mathrm{C}-\mathrm{NMR}$ data of bisezakyne-B were obtained in benzene- $d_{6}$, two chemical shifts, C- 6 and C-10 differed substantially and indicated that substituent were different. For bisezakyne-B, C-6, and C-10 both carry a chlorine atom with chemical shifts at 62.7 and $61.2 \mathrm{ppm}$ respectively. For compound 20, and according to chemical shift values, there might be a hydroxyl group at C-10 (69.95 ppm) and a bromine at C-6 (55.52 ppm). Then, compound 20 was submitted to ESI-Ion trap mass spectrometry which confirmed the presence of one hydroxyl and one acetoxyl group. The ESI-IT mass spectra revealed an adduct $[\mathrm{M}+\mathrm{Na}]^{+}$at $m / z$ 475 in positive mode and an adduct $\left[\mathrm{M}+\mathrm{Cl}^{-}\right.$at $\mathrm{m} / z 487$ in negative mode, indicating a molecular 
weight of $452 \mathrm{~g} / \mathrm{mol}$. Both signals showed an isotopic pattern with a 1:2:1 ratio, characteristic of the presence of two bromine atoms in the molecule. These data allowed the establishment of the formula $\mathrm{C}_{17} \mathrm{H}_{24} \mathrm{Br}_{2} \mathrm{O}_{4}$ for compound 20 (Figure S2). We suggest the name sagonenyne for this new compound which is the third $\mathrm{C}_{15}$-acetogenin containing a single tetrahydropyran ring isolated from a Laurencia species.

The relative stereochemistry of substituent on the tetrahydropyran ring has been established according to $J$ values in ${ }^{1} \mathrm{H}-\mathrm{NMR}$. Protons $\mathrm{H}-9$ to $\mathrm{H}-13$ exhibited identical coupling constant values to those from bisezakyne-B, ensuring the relative cis stereochemistry of C-13-ethyl and the carbon chain borne by C-9 in the tetrahydropyran ring (Figure 2). However, configuration of H-6 and H-7 remained unsure.<smiles>C#C/C=C/CC(Br)C(C)C[C@H]1O[C@H](CC)[C@@H](Br)C[C@H]1O</smiles>

sagonenyne<smiles>C#C/C=C/CC(Cl)C(C[C@H]1O[C@H](CC)[C@@H](Br)C=C1Cl)O[Na]</smiles><smiles>C#C/C=C\CCC(=O)C[C@H]1O[C@H](CC)[C@@H](Br)C[C@H]1O</smiles>

scanlonenyne

Figure 2. Structures of sagonenyne, bisezakyne-B, and scanlonenyne.

Table 3. NMR spectroscopic data (400 MHz, $\left.\mathrm{CDCl}_{3}\right)$ of sagonenyne (20).

\begin{tabular}{|c|c|c|c|c|c|c|}
\hline $\mathrm{C}$ & $\delta^{13} \mathrm{C}(\mathrm{ppm})$ & DEPT & $\delta^{1} \mathbf{H}(\mathrm{ppm})$ & Multiplicity ( $(\mathrm{Hz}))$ & $\operatorname{COSY}^{1} \mathbf{H}-{ }^{1} \mathbf{H}$ & $\mathrm{HMBC} \mathrm{H} \rightarrow \mathrm{C}$ \\
\hline 1 & 81.55 & $\mathrm{CH}$ & 2.85 & $\mathrm{~d}(2.0)$ & & $\mathrm{C} 3 ; \mathrm{C} 4$ \\
\hline 2 & 77.21 & $\mathrm{C}$ & - & - & & \\
\hline 3 & 112.13 & $\mathrm{CH}$ & 5.55 & $\mathrm{dd}(15.9,2.0)$ & H4; H1 & $\mathrm{C} 2 ; \mathrm{C} 4 ; \mathrm{C} 5$ \\
\hline 4 & 141.29 & $\mathrm{CH}$ & 6.22 & $\operatorname{dt}(15.9,7.1)$ & $\mathrm{H} 4 ; \mathrm{H} 5 \mathrm{a} ; \mathrm{H} 5 \mathrm{~b}$ & $\mathrm{C} 1 ; \mathrm{C} 3 ; \mathrm{C} 5 ; \mathrm{C} 6$ \\
\hline \multirow[t]{2}{*}{5} & 38.77 & $\mathrm{CH}_{2}$ & a 2.55 & $\mathrm{~m}$ & $\mathrm{H} 6$ & $\mathrm{C} 3 ; \mathrm{C} 4 ; \mathrm{C} 6 ; \mathrm{C} 7$ \\
\hline & & & b 2.70 & $\mathrm{~m}$ & H6 & $\mathrm{C} 2 ; \mathrm{C} 4 ; \mathrm{C} 6 ; \mathrm{C} 7$ \\
\hline 6 & 55.52 & $\mathrm{CH}$ & 4.04 & ddd $(9.0,4.9,2.7)$ & H5a; H5b; H7 & $\mathrm{C} 4 ; \mathrm{C} 5$ \\
\hline 7 & 71.38 & $\mathrm{CH}$ & 5.23 & $\mathrm{dt}(9.0,2.7)$ & $\mathrm{H} 8 \mathrm{a} ; \mathrm{H} 8 \mathrm{~b} ; \mathrm{H} 6$ & $\mathrm{C} 5 ; \mathrm{C} 8 ; \mathrm{C} 9$ \\
\hline \multirow[t]{2}{*}{8} & 35.35 & $\mathrm{CH}_{2}$ & a 1.78 & ddd $(14.8,9.0,2.3)$ & $\mathrm{H} 7$ & C6 \\
\hline & & & b 2.04 & $\mathrm{~m}$ & H9 & C9 \\
\hline 9 & 76.25 & $\mathrm{CH}$ & 3.43 & ddd $(10.7,2.5,1.0)$ & H8a; H8b; H10 & $\mathrm{C} 8 ; \mathrm{C} 10 ; \mathrm{C} 13$ \\
\hline 10 & 69.95 & $\mathrm{CH}$ & 3.64 & br t & H11a; H11b & C12 \\
\hline \multirow[t]{2}{*}{11} & 43.42 & $\mathrm{CH}_{2}$ & a 2.12 & $\mathrm{~m}$ & H10; H12 & $\mathrm{C} 12 ; \mathrm{C} 13$ \\
\hline & & & b 2.58 & $\mathrm{~m}$ & H10; H12 & $\mathrm{C} 9 ; \mathrm{C} 12 ; \mathrm{C} 13$ \\
\hline 12 & 47.50 & $\mathrm{CH}$ & 3.97 & ddd $(12.3,10.2,4.8)$ & H11a; H11b; H13 & $\mathrm{C} 11 ; \mathrm{C} 12 ; \mathrm{C} 14$ \\
\hline 13 & 83.98 & $\mathrm{CH}$ & 3.29 & ddd $(10.4,9.0,2.5)$ & $\mathrm{H} 14 \mathrm{a} ; \mathrm{H} 14 \mathrm{~b} ; \mathrm{H} 12$ & $\mathrm{C} 9 ; \mathrm{C} 11 ; \mathrm{C} 12 ; \mathrm{C} 14 ; \mathrm{C} 15$ \\
\hline \multirow[t]{2}{*}{14} & 26.35 & $\mathrm{CH}_{2}$ & a 1.48 & $\mathrm{~m}$ & $\mathrm{H} 13$ & $\mathrm{C} 12 ; \mathrm{C} 13 ; \mathrm{C} 15$ \\
\hline & & & b 2.06 & $\mathrm{~m}$ & H15 & $\mathrm{C} 12 ; \mathrm{C} 13 ; \mathrm{C} 15$ \\
\hline 15 & 9.63 & $\mathrm{CH}_{3}$ & 0.99 & $\mathrm{t}(7.4)$ & $\mathrm{H} 14 \mathrm{a} ; \mathrm{H} 14 \mathrm{~b}$ & $\mathrm{C} 13 ; \mathrm{C} 14$ \\
\hline \multirow{2}{*}{ Ac } & 20.87 & $\mathrm{CH}_{3}$ & 2.13 & $\mathrm{~s}$ & & \\
\hline & 170.19 & $\mathrm{C}$ & - & - & & \\
\hline
\end{tabular}




\subsection{Cytotoxic Activity}

The potential cytotoxic effect of the extract against a panel of different cancer cell lines, was evaluated using the resazurin assay. In order to increase the scope of this work, we selected three human tumor-derived cell lines from different origins: a leukemia monocytic cell line (THP-1), a sarcoma cell line from an osteosarcoma (MNNG-HOS), and also an epithelial cell line from a lung adenocarcinoma (A549). Data have revealed that the extract reduced cell viability in a dose dependent way (Figure 3). The effect of extract on cell viability was also cell type dependent. Overall, THP-1 cells $\left(\mathrm{IC}_{50}=153.2 \mu \mathrm{g} / \mathrm{mL}\right)$, followed by MNNG-HOS cells $\left(\mathrm{IC}_{50}=191.3 \mu \mathrm{g} / \mathrm{mL}\right)$, exhibited a high sensivity to the extract, whereas the A549 cell line was less sensitive, presenting the highest $\mathrm{IC}_{50}$ value $(446 \mu \mathrm{g} / \mathrm{mL})$ (Table 4).

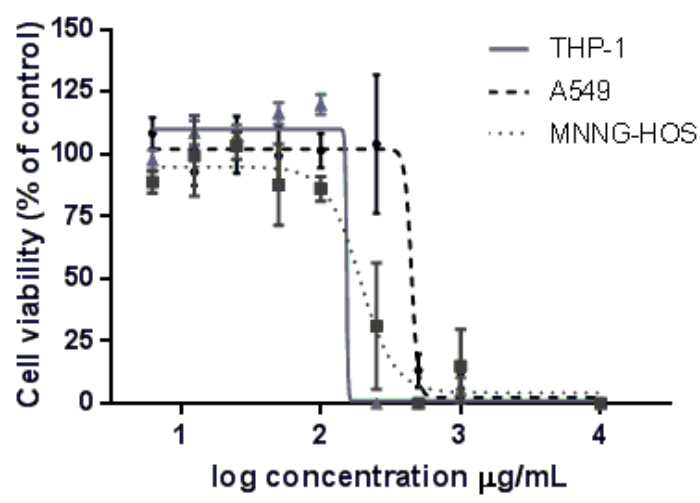

Figure 3. Dose-response effect of Laurencia obtusa crude extract on cell viability in different cancer cell lines. Cells were treated with different concentrations of crude extract for $24 \mathrm{~h}$. Data-points correspond to the mean \pm SEM of at least three independent assays. Dose-response curves were fitted to a sigmoidal function to calculate the $\mathrm{IC}_{50}$ values.

Table 4. $\mathrm{IC}_{50}$ values $(\mu \mathrm{g} / \mathrm{mL})$ of Laurencia obtusa crude extract in different cancer cell lines.

\begin{tabular}{cc}
\hline Cell Lines & Laurencia obtusa \\
\hline MNNG-HOS & 191.3 \\
THP-1 & 153.2 \\
A549 & 446.0 \\
\hline
\end{tabular}

\section{Discussion}

Analysis of L. obtusa extract by ${ }^{13} \mathrm{C}-\mathrm{NMR}$ allowed the identification of 24 components including sesquiterpenes, $\mathrm{C} 15$-acetogenins, diterpenes, and sterols. The extract is rich in sesquiterpenes and its composition is dominated by $\beta$-snyderol. The sesquiterpenes identified in this extract have several skeletons-cyclofarnesane, brasilane, laurane, or cuparane-which are usually found in terrestrial plants essential oils or extracts [32]. They are also commonly identified in marine organisms, and in particular in Laurencia species, but these molecules usually carry one or several halogen atom.

Acetogenins are relatively common in some plant families and especially Annonaceae. These molecules possess in general 35 or 37 carbons and an ether group, but no halogen. They are also well known for their bioactivities. Algal acetogenins are smaller molecules $\left(C_{15}\right)$ and most of them are halogenated. Investigations on acetogenins isolated from Laurencia species suggest that they might be chemotaxonomic markers for the genus. In particular, the determination of the type of the structure (linear, monocyclic, or polycyclic) and the size of the ether ring could be useful in chemotaxonomical approaches [33].

Diterpenes are commonly found in marine organisms and have original skeletons compared to those of terrestrial origin [34]. As for sesquiterpenes, diterpenes are mostly mono- or polyhalogenated. 
In this extract, few diterpenes were identified, including two molecules previously identified in a Laurencia species.

We describe here a large panel of secondary metabolites identified from a Laurencia obtusa extract. It is well known that the metabolome and biosynthetic pathways are most of the time characteristic of one species $[35,36]$. However the diversity of the Laurencia complex, which has previously led to wrong identification of the species [2], and the constant discovery of new components isolated from these species, avoid to establish a relation between a type of molecule and a species. Furthermore, it is noticeable that the group of acetogenins containing eight-membered cyclic ethers is the largest group among C15-acetogenins isolated from Laurencia species or mollusks feeding on them. In contrast, only five acetogenins exhibiting one single tetrahydropyran ring have been identified: two from Aplysia species, one from a Laurencia sp. (bisezakyne-B), and two from a L. obtusa: scanlonenyne and sagonenyne, a new compound. This observation could constitute a marker for this species.

Besides, the ${ }^{13} \mathrm{C}-\mathrm{NMR}$ method appeared to be a convenient method to describe the metabolite content of a species since it permits simultaneous identification of many compounds that possess a wide range of skeletons. Among them, several epimers and isomers-which might exhibit the same mass spectra-are easily identified using ${ }^{13} \mathrm{C}-\mathrm{NMR}$ chemical shifts.

In order to explore the cytotoxicity of the extract from Laurencia obtuse, we have chosen three human cancer lines in order to evaluate whether this cytotoxic effect was cell type dependent. Interestingly, the human leukemia monocytic cell line (THP-1) and the osteosarcoma cell lines (MNNG-HOS) showed higher sensitivity to the extract, while the epithelial cell line from lung adenomarcinoma was the less sensitive to the extract. From our knowledge, this is the first study addressing the antiproliferative effect of L. obtusa extract in THP-1 and MNNG-HOS cells. Regarding A549 cells, Dellai et al. 2013 [37] evaluated the antiproliferative activity of a methanolic extract of L. obtusa. However, we cannot directly compare the results obtained in both studies since the extraction method was different and consequently, the chemical composition is quite dissimilar from our extract. Indeed, Dellai et al. extracted mainly phenolic compounds.

Some of the secondary metabolites of L. obtusa extract were previously reported as cytotoxic compounds. For instance, sesquiterpenes found in our extract-laurinterol and iso-laurenisol—exhibited cytotoxic activity in several human cell lines, such as MCF7, PC3, HeLa, and A431 cells [5]. Furthermore, related compounds-namely laurane and cuparane skeleton sesquiterpenes-isolated from Laurencia species also have cytotoxic activities in human tumor cells [4,38]. Conversely, to the best of our knowledge, the cytotoxic activity and anticancer potential of the main compound of our extract- $\beta$-snyderol—was never addressed. Therefore, future studies are needed to explore the anticancer potential of $\beta$-snyderol and other major compounds of the extract, and also to evaluate if the cytotoxic effect described in this study is due to a single molecule or to synergistic effects achieved by two or more compounds.

\section{Materials and Methods}

\subsection{Plant Material}

Laurencia obtusa (Hudson) J. V. Lamouroux has been collected in Sagone bay (Corsica, France, GPS point: $42^{\circ} 06.432^{\prime} \mathrm{N}, 8^{\circ} 40.278^{\prime} \mathrm{E}$ ) during July 2015. A voucher specimen (H8314) was deposited at the Verlaque Herbarium (Institut Méditerranéen d'Océanologie, Université d'Aix Marseille). Identification of the specimen was performed by Dr. Line Le Gall (Institut de Systématique, Evolution Biodiversité-Museum National d'Histoire Naturelle, Paris, France) based on molecular phylogenies.

\subsection{Extraction and Separation}

Algae were washed with tap water and dried with a lyophilizer. The algae powder of Laurencia obtusa (531.8 g) were extracted with ethyl acetate at room temperature and the solvent 
was removed under reduced pressure to yield a crude extract $(4.9 \mathrm{~g})$. This extract has directly been subjected to ${ }^{13} \mathrm{C}-\mathrm{NMR}$ analysis affording the identification of compounds $\mathbf{1}$ to 5 .

Three grams of L. obtusa extract were fractioned on flash chromatography $\left(\mathrm{SiO}_{2} 60 \mathrm{~A}, 63-200 \mu \mathrm{m}\right)$ with a gradient of mixtures of pentane-chloroform-ethyl acetate-methanol to yield 17 fractions and submitted to ${ }^{13} \mathrm{C}-\mathrm{NMR}$ analysis affording the identification of compounds $\mathbf{6}$ to 19 and 21 to 24 . Fractions F6 to F9 were combined and submitted to repeated chromatography on silica gel using a gradient of solvents and size-exclusion on Sephadex LH-20 to yield the new compound sagonenyne (compound 20; $1.2 \mathrm{mg}$ ).

\subsection{NMR Analysis}

All ${ }^{13} \mathrm{C}$-NMR spectra were recorded on a Bruker AVANCE 400 Fourier Transform spectrometer operating at $100.13 \mathrm{MHz}$, equipped with a $5 \mathrm{~mm}$ probe, in deuterated chloroform $\left(\mathrm{CDCl}_{3}\right)$, with all shifts referred to internal tetramethylsilane (TMS). Spectra were recorded with the following parameters: pulse width (PW), $4 \mu \mathrm{s}$ (flip angle $45^{\circ}$ ); acquisition time, $2.7 \mathrm{~s}$ for $128 \mathrm{~K}$ data table with a spectral width (SW) of $24,000 \mathrm{~Hz}(240 \mathrm{ppm})$; CPD mode decoupling, digital resolution $0.183 \mathrm{~Hz} / \mathrm{pt}$. The number of accumulated scans was 3000 for both samples ( $50 \mathrm{mg}$ in $0.5 \mathrm{~mL}$ of $\mathrm{CDCl}_{3}$ ).

2D NMR data for compound 20 were recorded on a Bruker AVANCE DRX500 spectrometer operating at $125.56 \mathrm{MHz}$ for ${ }^{13} \mathrm{C}$ and $499.35 \mathrm{MHz}$ for ${ }^{1} \mathrm{H}$, equipped with a $1.7 \mathrm{~mm}$ TXI probe, in deuterated chloroform $\left(\mathrm{CDCl}_{3}\right)$. COSY spectrum was recorded using 1024 data points in F2 dimension and 256 in F1 dimension, a spectral width (SW) of 8 ppm in both dimensions, and an accumulation of 32 scans. HMQC and HMBC spectra were recorded using 1024 data points in F2 and 256 in $\mathrm{F} 1$ dimension, spectral widths (SW) of 8 ppm in F2 dimension $\left({ }^{1} \mathrm{H}\right)$ and of $250 \mathrm{ppm}$ in F1 dimension $\left({ }^{13} \mathrm{C}\right)$, and accumulation of 64 scans for HMQC and 256 for HMBC.

\subsection{Mass Spectrometry}

Mass analyses were performed in both positive and negative modes, on an Esquire 3000 PLUS ESI ion trap mass spectrometer equipped with an electrospray source (Bruker, Wissembourg, France). The conditions were as follows: spray voltage of $4.5 \mathrm{kV}$, nebulizer and drying gas, $\mathrm{N}_{2}, 4 \mathrm{~L} / \mathrm{min}$; pressure of nebulizer gas, $10 \mathrm{psi}$; dry temperature, $250{ }^{\circ} \mathrm{C}$.

\subsection{Identification of the Components}

Identification of components was based on ${ }^{13} \mathrm{C}-\mathrm{NMR}$ spectroscopy, following a computerized method developed in our laboratory using homemade software; by comparison of the chemical shift values of the signals in the spectra with those of reference compounds compiled in a literature library build in our laboratory. This library contains different kinds of molecules from marine organisms (about 2000): mono-, sesqui-, and diterpenes with various skeletons; sterols; C15-acetogenins; fatty acids; etc.

\subsection{Cell Culture}

THP-1 (human leukemia monocytic cell line; ATCC ${ }^{\circledR}$ TIB-202 $^{\mathrm{TM}}$ ) and MNNG-HOS (human osteosarcoma cell line; ATCC ${ }^{\circledR}$ CRL-1547 ${ }^{\mathrm{TM}}$ ) cells were cultured in RPMI-1640 medium with L-Glutamine, and A549 cells (human lung adenocarcinoma epithelial cells; ATCC ${ }^{\circledR}$ CCL-185 ${ }^{\mathrm{TM}}$ ) in DMEM with $5 \mathrm{~g} / \mathrm{L}$ of glucose. All mediums contained $10 \%(v / v)$ heat-inactivated fetal bovine serum, $100 \mathrm{U} / \mathrm{mL}$ penicillin and $100 \mu \mathrm{g} / \mathrm{mL}$ streptomycin. Cells were maintained at $37{ }^{\circ} \mathrm{C}$ and $5 \% \mathrm{CO}_{2}$ in a humidifier incubator.

\subsection{Assessment of Cell Viability}

Cell viability was evaluated by the resazurin assay [39] in which metabolic active cells reduce resazurin (blue) into resorufin (pink). Therefore, the magnitude of dye reduction is correlated with 
the number of viable cells. THP-1 $\left(18 \times 10^{4}\right)$, MNNG-HOS $\left(6 \times 10^{4}\right)$ and A549 $\left(6 \times 10^{4}\right)$ cells were plated in 48-well plates and allowed to stabilize for $12 \mathrm{~h}$. The crude extract of L. obtusa was diluted firstly in DMSO and, subsequently, in culture medium. Then, cells were incubated with sequential concentrations of crude extract (from 0.781 to $1000 \mu \mathrm{g} / \mathrm{mL}$ ) and controls cells were treated with the same concentrations of DMSO (the highest concentration used was $0.4 \%$ of DMSO) for $24 \mathrm{~h}$.

Concerning A549 and MNNG-HOS cells, resazurin $(50 \mu \mathrm{M})$ was added to the cells $1 \mathrm{~h}$ before fluorescence recording, while for THP- 1 the incubation with resazurin was performed for $3 \mathrm{~h}$. Absorbance was read using a standard spectrophotometer (Vienna, Austria) at $570 \mathrm{~nm}$, with a reference wavelength of $620 \mathrm{~nm}$. Treated cells were compared to the respective controls and the $\mathrm{IC}_{50}$ value, representing the concentration required to inhibit $50 \%$ of cell viability, was calculated via nonlinear regression.

Supplementary Materials: The following are available online. Figure S1: 2D NMR spectra of sagonenyne (20), Figure S2: ESI Mass spectrum of sagonenyne (20), Figure S3: Structures of compounds identified in the crude extract.

Acknowledgments: Authors thank the "Collectivité Territorial de Corse" for partial financial support ("Marina cosmétique" project).

Author Contributions: V.C. and M.P. conceptualized the "Marina cosmétique" project and A.B. led the project; H.E. and S.S. conceived and designed the experiments; H.E. performed sampling, extractions, and NMR experiments (400 MHz); B.S. performed the NMR experiments (500 MHz); J.L. and M.T.C performed the cytotoxicity; I.F. performed the MS experiments; H.E., L.S., and F.T. analyzed the data and wrote the paper.

Conflicts of Interest: The authors declare no conflict of interest.

\section{References}

1. Wang, B.G.; Gloer, J.B.; Ji, N.Y.; Zhao, J.C. Halogenated organic molecules of rhodomelaceae origin: Chemistry and biology. Chem. Rev. 2013, 113, 3632-3685. [CrossRef] [PubMed]

2. Harizani, M.; Ioannou, E.; Roussis, V. The Laurencia paradox: An endless source of chemiodiversity. Prog. Chem. Org. Nat. Prod. 2016, 102, 91-252.

3. Lhullier, C.; Falkenberg, M.; Ioannou, E.; Quesada, A.; Papazafiri, P.; Horta, P.A.; Schenkel, E.P.; Vagias, C.; Roussis, V. Cytotoxic Halogenated Metabolites from the Brazilian Red Alga Laurencia catarinensis. J. Nat. Prod. 2010, 73, 27-32. [CrossRef] [PubMed]

4. Kladi, M.; Vagias, C.; Furnari, G.; Moreau, D.; Roussakis, C.; Roussis, V. Cytotoxic cuparene sesquiterpenes from Laurencia microcladia. Tetrahedron Lett. 2005, 46, 5723-5726. [CrossRef]

5. Kladi, M.; Xenaki, H.; Vagias, C.; Papazafiri, P.; Roussis, V. New cytotoxic sesquiterpenes from the red algae Laurencia obtusa and Laurencia microcladia. Tetrahedron 2006, 62, 182-189. [CrossRef]

6. Sutour, S.; Xu, T.; Casabianca, H.; Paoli, M.; de Rocca-Serra, D.; Tomi, F.; Garrido, M.; Pasqualini, V.; Aiello, A.; Castola, V.; et al. Chemical composition of extracts from Chaetomorpha linum (Miller) Kütz. A potential use in the cosmetic industry. Int. J. Phytocosmet. Nat. Ingred. 2015, 2, 5.

7. Xu, T.; Sutour, S.; Casabianca, H.; Tomi, F.; Paoli, M.; Garrido, M.; Pasqualini, V.; Aiello, A.; Castola, V.; Bighelli, A. Rapid screenig of chemical compositions of Gracilia dura and Hypnea musciformis (Rhodophyta) from Corsican Lagoon. Int. J. Phytocosmet. Nat. Ingred. 2015, 2, 8.

8. Tomi, F.; Casanova, J. ${ }^{13} \mathrm{C}-\mathrm{NMR}$ as a tool for identification of individual components of essential oils from Labiatae A review. Acta Hortic. 2006, 723, 185-192. [CrossRef]

9. Bazzali, O.; Huy Thai, T.; Minh Hoi, T.; Sinh Khang, N.; Thi Hien, N.; Casanova, J.; Bighelli, A.; Tomi, F. Integrated analysis of the wood oil from Xanthocyparis vietnamensis Farjon \& Hiep. by chromatographic and spectroscopic techniques. Molecules 2016, 21, 840.

10. Rezzi, S.; Bighelli, A.; Castola, V.; Casanova, J. Direct identification and quantitative determination of acidic and neutral diterpenes using ${ }^{13}$ C-NMR spectroscopy. J. Appl. Spectrosc. 2002, 56, 312-317. [CrossRef]

11. Blanc, M.C.; Bradesi, P.; Gonçalves, M.J.; Salgueiro, L.; Casanova, J. Essential oil of Dittrichia viscosa ssp. viscosa: Analysis by ${ }^{13} \mathrm{C}-\mathrm{NMR}$ and antimicrobial activity. Flavour Fragr. J. 2006, 21, 324-332. [CrossRef]

12. Gonny, M.; Bradesi, P.; Casanova, J. Identification of the components of the essential oil from wild Corsican Daucus carota L. using ${ }^{13}$ C-NMR spectroscopy. Flavour Fragr. J. 2004, 19, 424-433. [CrossRef] 
13. Howard, B.M.; Fenical, W. $\alpha$ - and $\beta$-snyderol; new bromo-monocyclic sesquiterpenes from the seaweed Laurencia. Tetrahedron Lett. 1976, 1, 41-44. [CrossRef]

14. Amico, V.; Caccamese, S.; Neri, P.; Russo, G.; Foti, M. Brasilane-type sesquiterpenoids from the Mediterranean red alga Laurencia obtusa. Phytochemistry 1991, 30, 1921-1927. [CrossRef]

15. Stallard, M.O.; Fenical, W. The brasilenols, rearranged sesquiterpenes alcohols isolated from the marine opsthobranch Aplysia brasilana. Tetrahedron 1978, 34, 2077-2081. [CrossRef]

16. Kazlauskas, R.; Murphy, P.T.; Quinn, R.J.; Wells, R.J. New laurene derivatives from Laurencia filiformis. Aust. J. Chem. 1976, 29, 2533-2539. [CrossRef]

17. Kadi, M.; Vagias, C.; Papazafiri, P.; Furnari, G.; Serio, D.; Roussis, V. New sesquiterpens from the red alga Laurencia microcladia. Tetrahedron 2007, 63, 7606-7611.

18. Zhang, J.; Ding, L.P.; Liang, H.; Guo, X.Y.; Zhang, Q.Y. Sesquiterpenes from the red alga Laurencia tristicha. Biochem. Syst. Ecol. 2015, 60, 116-119. [CrossRef]

19. König, G.M.; Wright, A.D. New C15-acetogenins and sesquiterpenes from the red alga Laurencia sp cf. L. gracilis. J. Nat. Prod. 1994, 57, 477-485.

20. Suzuki, M.; Kurosawa, E. New aromatic sesquiterpenoids from the red alga Laurencia yamada (1). Tetrahedron Lett. 1978, 28, 2503-2506.

21. Izac, R.R.; Sims, J.J. Marine Natural Products. 18. Iodinated sesquiterpenes from the red algal genus Laurencia. J. Am. Chem. Soc. 1979, 101, 6136-6137. [CrossRef]

22. Boeckman, R.K., Jr.; Zhang, J.; Reeder, M.R. Synthetic and mechanistic studies of the retro-claisen rearrangement 4. an application to the total synthesis of (+)-laurenyne. Org. Lett. 2002, 4, 3891-3894. [CrossRef] [PubMed]

23. Norte, M.; Gonzales, A.G.; Cataldo, F.; Rodriguez, M.L.; Brito, I. New examples of acyclic and cyclic C-15 actogenins from Laurencia pinnatifida. Reassignment of the absolute configuration for $\mathrm{E}$ and $\mathrm{Z}$ pinnatifidenyne. Tetrahedron 1991, 47, 9411-9418.

24. Iliopoulou, D.; Vagias, C.; Harvala, C.; Roussis, V. C15-acetogenins from the red alga Laurencia obtusa. Phytochemistry 2002, 59, 111-116. [CrossRef]

25. Norte, M.; Fernandez, J.J.; Cataldo, F.; Gonzales, A.G. E-dihydrorhodophytin, a C15-acetogenin from the red alga Laurencia pinnatifida. Phytochemistry 1989, 28, 647-649. [CrossRef]

26. Guella, G.; Pietra, F. A new-skeleton diterpenoid, new prenylbisabolanes, and their putative biogenetic precursor, from the red seaweed Laurencia microcladia from II Rogiolo: Assigning the absolute configuration when two chiral halves are connected by single bonds. Helv. Chim. Acta 2000, 83, 2946-2952. [CrossRef]

27. Howard, B.M.; Fenical, W. Obtusadiol, a unique bromoditerpenoid from the marine red alga Laurencia obtusa. Tetrahedron Lett. 1978, 28, 2453-2456. [CrossRef]

28. Wright, J.L.C.; McInnes, A.G.; Shimizu, S.; Smith, D.G.; Walter, J.A.; Idler, D.; Khalil, W. Identification of C-24 alkyl epimers of marine sterols by ${ }^{13} \mathrm{C}$ nuclear magnetic resonance spectroscopy. Can. J. Chem. 1978, 56, 1898-1903.

29. McInnes, A.G.; Walter, J.A.; Wright, J.L.C. ${ }^{13}$ C-NMR spectra of $\Delta^{24(28)}$ phytosterols. Magn. Reson. Chem. 1980, 13, 302-303. [CrossRef]

30. Suzuki, M.; Nakano, S.; Takahashi, Y.; Abe, T.; Masuda, M. Bisezakyne-A and -B, halogenated $C_{15}$-acetogenins from a Japanese Laurencia species. Phytochemistry 1991, 51, 657-662. [CrossRef]

31. Suzuki, M.; Takahashi, Y.; Matsuo, Y.; Guiry, M.D.; Masuda, M. Scanlonenyne, a novel halogenated C15-acetogenin from the red alga Laurencia obtusa on Irish waters. Tetrahedron 1997, 12, 4271-4278. [CrossRef]

32. Joulain, D.; König, W.A. The Atlas of Spectral Data of Sesquiterpenes Hydrocarbons; E.B.-Verlag: Hamburg, Germany, 1998.

33. Wanke, T.; Phillippus, A.C.; Zatelli, G.A.; Vieira, L.F.O.; Lhullier, C.; Falkenberg, M. C15-acetogenins from the Laurencia complex: 50 years of research-An overview. Rev. Bras. Farmacogn. 2015, 25, 569-587. [CrossRef]

34. Kornprobst, J.M. Substances Naturelles D'origine Marine; Lavoisier: Paris, France, 2005.

35. Masuda, M.; Kogame, K.; Arisawa, S.; Suzuki, M. Morphology and halogenated secondary metabolites of three Gran Canaria species of Laurencia (Ceremiales, Rhodophyta). Bot. Mar. 1998, 41, 265-277. [CrossRef]

36. Suzuki, M.; Vairappan, C.S. Halogenated secondary metabolites from Japanese species of the red algal gens Laurencia (Rhodomelaceae, Ceremiales). Curr. Top. Phytochem. 2005, 5, 1-38.

37. Dellai, A.; Laajili, S.; Le Morvan, V.; Robert, J.; Bouraoui, A. Antiproliferative activity and phenolics of the Mediterranean seaweed Laurencia obtusa. Ind. Crops Prod. 2013, 47, 252-255. [CrossRef] 
38. Angawi, R.F.; Alarif, W.M.; Rehab, F.; BAdria, F.A.; Ayyad, S.E.N. New cytotoxic laurene-, cuparene-, and laurokamurene-type sesquiterpenes from the red alga Laurencia obtusa. Helv. Chim. Acta 2014, 97, 1388-1395. [CrossRef]

39. O'Brien, J.; Wilson, I.; Orton, T.; Pognan, F. Investigation of the Alamar Blue (resazurin) fluorescent dye for the assessment of mammalian cell cytotoxicity. Eur. J. Biochem. 2000, 267, 5421-5426. [CrossRef] [PubMed]

Sample Availability: Not available.

(C) 2017 by the authors. Licensee MDPI, Basel, Switzerland. This article is an open access article distributed under the terms and conditions of the Creative Commons Attribution (CC BY) license (http:// creativecommons.org/licenses/by/4.0/). 